\title{
RELATIONSHIP BETWEEN THE CELLULAR PRION LEVEL AND ATPases ACTIVITIES IN THE LIVER AND KIDNEYS OF DIFFERENT AGE WISTAR LINE RATS
}

\author{
M. Kushkevych, N. Kuzmina, V. Vlizlo \\ m_kushkevych@ukr.net
}

Institute of Animal Biology of NAAS,

38 Vasyl Stus str., Lviv 79034, Ukraine

Transmissible spongioform encephalopathies (TSE) are the central nervous system diseases, the pathological agent of which is the infectious prion $\left(\operatorname{Pr}^{\mathrm{Sc}}\right)$. Its precursor is the cellular prion $\left(\operatorname{Pr} P^{C}\right)$, which is localized on the cell membrane and performs many important metabolic functions. However, in unknown conditions it can convert the conformation in the pathological form and cause neurodegeneration. Given that the sporadic cases are registered especially in middle age people, the $\operatorname{Pr}^{C}$ age dynamics study is relevant. The $\operatorname{Pr} P^{C}$ involvement in the regulation of $\mathrm{Ca}^{2+}$-channels and calcium homeostasis is described. In conditions of its conversion into the pathological form the $\mathrm{PrP}^{\mathrm{C}}$ is not able to perform its function. It causes a violation of different methabolic pathways.

Age dynamics of the cellular prion molecular isoforms quantitative content is detected. Studies were carried out in the laboratory animals' liver and kidneys by Western blot analysis. PrPC level reduction by 41-57\% in old animals compared to mature animals is demonstrated. $\mathrm{Na}^{+} / \mathrm{K}^{+}$- and $\mathrm{Ca}^{2+}$-ATPases activity in different ages rats' prion replicating tissues is determined. A sharp ion transporters activity decreasing (by 48-86\%) in thirty months animals'liver and kidneys is showing. Based on the kinetic analysis results of the ATP hydrolysis by studied enzymes the kinetic parameters (initial reaction velocity, maximum amount of reaction product, Michaelis constant and maximum velocity of enzymatic reaction) significant decrease is established. In the thirty months animals'liver and kidneys the $\mathrm{Ca}^{2+}$-ATPases remain its activity under high calcium ions concentration in the medium. It should be noted that the ions concentration value optimum for the $\mathrm{Na}^{+} / \mathrm{K}^{+}$-ATPase is shifting towards the $\mathrm{Na}^{+}$level increase which is consistent with a increasing of these ions by 4-10\% in the tissues as a whole. Using the correlation analysis method a strong direct correlation between the cellular prion level and studied ion transporters activities is demonstrated $(r=0.754-0.889)$.

Keywords: RATS, LIVER, KIDNEYS, AGE CHANGES, CELLULAR PRION, WESTERN BLOTTING, $\mathrm{Na}^{+} / \mathrm{K}^{+}$- AND $\mathrm{Ca}^{2+}$-ATPases

\section{ВЗАЕМОЗВ'ЯЗОК МІЖ ВМІСТОМ КЛІТИННОГО ПРІОНА Й АКТИВНІСТЮ АТФ-аз У ПЕЧІНЦІ ТА НИРКАХ ЩУРІВ ЛІНІЇ WISTAR РІЗНОГО ВІКУ}

\author{
М. В. Кушкевич, Н. В. Кузьміна, В. В. Влізло \\ m_kushkevych@ukr.net
}

Інститут біології тварин НААН,

вул. В. Стуса, 38, Львів, 79034, Україна

Трансмісивні спонгіоформні енцефалопатії (ТCE) - ие захворювання иентральної нервової системи, збудником яких є патологічний (інфекційний) пріон ( $\mathrm{Pr} P \mathrm{Pc})$. Його попередником є клітинний пріон $\left(\operatorname{Pr} P^{C}\right)$, який локалізується на клітинній мембрані та виконує багато важслиих функиій метаболізму. Однак за невідомих умов він здатний набувати патологічної конформаиї̈ молекули та спричиняти нейродегенерації. За умов конверсії у патологічну форму $\operatorname{Pr}^{C}$ не здатний виконувати свою функиію. Це обумовлює порушення різних ланок метаболізму. Враховуючи те, щчо спорадичні випадки захворювання реєструються частіше в осіб зрілого віку, дослідження вікової динаміки $\operatorname{PrP}^{C} \epsilon$ актуальним. Описана участь $\operatorname{PrP}^{C}$ у регулюванні $\mathrm{Ca}^{2+}$-каналів та підтриманні гомеостазу кальиію.

У статті висвітлено вікову динаміку вмісту молекулярних ізоформ клітинного пріона. $\operatorname{Pr}^{C}$ та його ізоформи досліджували у печіниі та нирках лабораторних тварин методом вестерн блот аналізу. Встановлено зниження вмісту $\operatorname{Pr}^{C}$ на 41-57 \% у старих тварин порівняно зі зрілими. Визначено активність $\mathrm{Na}^{+}-\mathrm{K}^{+}$- та $\mathrm{Ca}^{2+}$-АТФ-аз у пріон-реплікувальних тканинах щурів різного віку. Показано різке зниження активності іонних транспортерів (на 48-86\%) у печінці та нирках тридиятимісячних тварин. 
За результатами кінетичного аналізу реакиії гідролізу АТФ досліджуваними ензимами, встановлено вірогідне зниження значень кінетичних параметрів (максимальна миттєва швидкість, максимальна кількість продукту, константа Міхаеліса та максимальна швидкість реакиії). У тканинах тридиятимісячних тварин $\mathrm{Ca}^{2+}$-АТФ-ази зберігають активність за високих концентрацій іонів кальцію у середовищі. Оптимум співвідношення кониентрації іонів для $\mathrm{Na}^{+}-\mathrm{K}^{+}-A T \Phi$-ази змішується у напрямку зростання вмісту $\mathrm{Na}^{+}$, що узгоджується зі зростанням на 4-10\% рівня изих іонів у тканинах загалом. За допомогою методу кореляційного аналізу встановлено сильну пряму кореляцію між вмістом клітинного пріона та активністю досліджуваних іонних транспортерів $(r=0,754-0,889)$.

Ключові слова: ЩУРИ, ПЕЧІНКА, НИРКИ, ВІКОВІ ЗМІНИ, КЛІТИННИЙ ПРІОН, ВЕСТЕРН БЛОТ, $\mathrm{Na}^{+}-\mathrm{K}^{+}-\mathrm{TA} \mathrm{Ca}{ }^{2+}$-АТФ-ази

\title{
ВЗАИМОСВЯЗЬ МЕЖДУ СОДЕРЖАНИЕМ КЛЕТОЧНОГО ПРИОНА И АКТИВНОСТЬЮ АТФ-аз В ПЕЧЕНИ И ПОЧКАХ КРЫС ЛИНИИ WISTAR РАЗНОГО ВОЗРАСТА
}

\author{
М. В. Кушкевич, Н. В. Кузьмина, В. В. Влизло \\ m_kushkevych@ukr.net
}

Институт биологии животных НААН,

ул. Стуса, 38, Львов, 79034, Украина

Трансмиссивные спонгиоформные энцефалопатии (ТСЭ) - это заболевание иентральной нервной системы, возбудителем которых является патологический (инфекиионный) прион (PrPsc). Предшественником его является клеточный прион $\left(\operatorname{Pr}^{C}\right)$, который локализуется на клеточной мембране и выполняет много важных функиий метаболизма. Однако по неизвестным причинам он способен приобретать патологическую конформацию молекулы и вызывать нейродегенерации. В условиях конверсии в патологическую форму $\operatorname{Pr}^{C}$ не способен выполнять свою функиию. Это обусловливает нарушение различных звеньев метаболизма. Учитывая то, что спорадические случаи заболевания регистрируются чаще у лии зрелого возраста, исследования возрастной динамики $\operatorname{PrP}^{C}$ является актуальнылм. Описано участие $\operatorname{Pr}^{C}$ в регулировании $\mathrm{Ca}^{2+}$-каналов и поддержании гомеостаза кальция.

У статье показано возрастную динамику содержания молекулярных изоформ клеточного приона. $\operatorname{Pr} P^{C}$ и его изоформы исследовали в печени и почках лабораторных животных методом вестерн блот анализа. Установлено снижение содержания $\operatorname{Pr}^{C}$ на 41-57\% у старых животных по сравнению со зрелыми. Определены активность $\mathrm{Na}^{+}-\mathrm{K}^{+}-$и $\mathrm{Ca}^{2+}$-АТФ-аз в прион-реплицирующих тканях крыс разного возраста. Показано резкое снижение активности ионных транспортеров (на 48-86\%) в печени и почках тридцатимесячных животных. По результатам кинетического анализа реакции гидролиза АТФ исследуемыми энзимами, установлено достоверное снижение значений кинетических параметров (максимальная мгновенная скорость, максимальное количество продукта, константа Михаэлиса и максимальная скорость реакиии). В тканях тридиатимесячных животных $\mathrm{Ca}^{2+}$-АТФ-азы сохраняют активность при высоких конщентрациях ионов кальция в среде. Оптимум соотношения концентрации

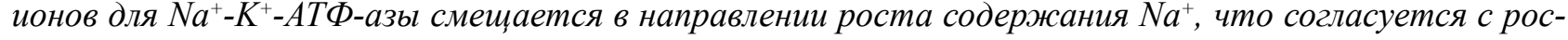
том уровня этих ионов на 4-10\% в тканях в ичелом. С помощью метода корреляиионного анализа установлено сильную прямую корреляиию между содержанием клеточного приона и активностью исследуемых ионных транспортеров $(r=0,754-0,889)$.

\section{КлючевЫе слова: КРЫСЫ, ПЕЧЕНЬ, ПОЧКИ, ВОЗРАСТНЫЕ ИЗМЕНЕНИЯ, КЛЕТОЧ- НЫЙ ПРИОН, ВЕСТЕРН БЛОТ, $\mathrm{Na}^{+}-\mathrm{K}^{+}-$И $\mathrm{Ca}^{2+}$-АТФ-азЫ}

Prion diseases are slow neurodegenerative disorders in humans and animals, which have a fatal effect $[1,2]$. The disease is a manifestation of molecular pathology in which cell (physiological) prion $\left(\mathrm{PrP}^{\mathrm{C}}\right)$ changes its structure and is transformed in pathological $\left(\mathrm{PrP}^{\mathrm{Sc}}\right)$ form [3]. The study of the physiological role of $\mathrm{PrP}^{\mathrm{C}}$ in cellular processes is an important for understanding the causes of neurodegeneration including direct effect of prions or loss of $\operatorname{PrP}^{\mathrm{C}}$ functionality.

PrP-knocked animals are immune to prion infections. They normally develop without 
neurodegenerative symptoms [4], but over time the neurophysiological and behavioral disorders arise in these animals [5-7].

$\mathrm{PrP}^{\mathrm{C}}$ is localized on the surface of mammalian cells and consists of sialic glycoproteins formed by about 210 amino acids, which is connected to the plasma membrane by glucosilphosphotidil-inositol fragment. The studies of $\mathrm{PrP}^{\mathrm{C}}$ functions in vitro and in vivo have shown that this protein is involved not only in copper metabolism and protection mechanisms against of oxidative stress and apoptosis but also in cell adhesion, migration, proliferation and differentiation, and interactions with extracellular components [8]. In addition, the cellular prion is involved in the synaptic structure formation and its functioning $[9,10]$. It maintains the $\mathrm{Ca}^{2+}$ homeostasis, influencing on the $\mathrm{Ca}^{2+}$-channels activity [11], but there is no data of its effect on the ATPases activity in the age dynamics.

Cellular prion as a precursor of pathological prion was founded in the brain, spleen, small intestine and skeletal muscles $[12,13]$. However, there are no information about its amount in the liver and kidneys of different age animals.

The aim of this study was to determine the expression level of cellular prion molecular forms, the activity of $\mathrm{Na}^{+} / \mathrm{K}^{+}$- and $\mathrm{Ca}^{2+}$-ATPases as well as the ions level in the liver and kidneys of different ages rats. These data will expand the scientific understanding of the possible causes of prion diseases sporadic occurrence.

\section{Materials and Methods}

Manipulation with the animals were carried out under the principles of the "European Convention for the Protection of Vertebrate Animals Used for Experimental and Other Scientific Purposes" (Strasbourg, 1986), the Decision of the First National Congress on Bioethics (Kyiv, 2001) and the Law of Ukraine "On Protection Animals from Brutal Treatment" (Kyiv, 2006).

Research was carried out on the males of laboratory rats Rattus norvegicus var. alba, Wistar line, which were held under standard vivarium conditions. The animals aged one, six and thirty months were decapitated under ether anesthesia, the liver and kidneys were selected for this research.

A western blotting analysis of the liver and kidneys was carried out. For that, the tissues were homogenized and lysed in a special buffer (10\% N-lauroylsarkozyn, $10 \mathrm{mM}$ of fenilmethylsulfonilftorid, $10 \mathrm{mM}$ of N-ethylmaleyimid in $0.01 \mathrm{M} \mathrm{Na}$-phosphate buffer), with the addition of $0.001 \%$ mixture of proteinase inhibitors (Sigma, Germany) as well as centrifuged for $2 \mathrm{~min}$ at $12.000 \times \mathrm{g}$ and at $4{ }^{\circ} \mathrm{C}$. The protein level was measured by Lowry method [14]. Lemli buffer was added to the supernatant (Sigma, Germany). Samples were heated during $5 \mathrm{~min}$ in $95^{\circ} \mathrm{C}$, after which the proteins were fractionated by electrophoresis in $12 \%$ gradient polyacrylamide gels (PAGE). The electro blotting of proteins on PVDF-membrane was carried (Millipore, USA). The samples with the same concentration of the protein were deposited in each PAGE well. SeeBluePlus2 (Invitrogen, USA) markers kit was used for transfer control and for the proteins relative molecular weight determination. After electro blotting the membranes were incubated for $60 \mathrm{~min}$ in 5\% non-fat milk, diluted by buffered saline with $0.01 \%$ Tween-20. The membranes were incubated with monoclonal primary antibodies (Antibody mAB6H4; Prionics, Switzerland) at $+4{ }^{\circ} \mathrm{C}$ for $12 \mathrm{~h}$, and secondary polyclonal goat anti-mouse antibodies which are conjugated with alkaline phosphatase (Sigma, Germany) at $+22{ }^{\circ} \mathrm{C}$ during $60 \mathrm{~min}$. Detection of the immune complexes was carried out using a substrate for alkaline phosphatase CDP-Star (Tropix, UK). Visualization was performed using X-ray film Retina XBM (Lizoform Medical, Ukraine) and film development kit for films (Kodak, Japan) [15].

To determine the $\mathrm{Na}^{+} / \mathrm{K}^{+}$- and $\mathrm{Ca}^{2+}$-ATPases activity the tissues samples were homogenized for 1-2 min at Omni GLH-220 homogenizer in the sucrose medium. As a result of repeated centrifugation the tissue membrane fraction was obtained $[16,17]$, in which the studied parameters were determined. The activity of $\mathrm{Na}^{+} / \mathrm{K}^{+}$ATPase was determine in the incubation medium of the following composition: $125 \mathrm{mM}$ of $\mathrm{NaCl}, 25 \mathrm{mM}$ of $\mathrm{KCl}, 5 \mathrm{mM}$ of $\mathrm{MgCl}_{2}, 5 \mathrm{mM}$ $\mathrm{Na}_{2}$ ATP, $1 \mathrm{mM}$ EGTA, $20 \mathrm{mM}$ of hepes-Tris- 
buffer, $0.2 \%$ saponin ( $\mathrm{pH} 7.4$ ). The activity of $\mathrm{Na}^{+} / \mathrm{K}^{+}$-ATPase was calculated by the difference between the total activity and ouabain insensitive activity, which was determined in medium with $1 \mathrm{mM}$ of ouabain (selective inhibitor of $\mathrm{Na}^{+} / \mathrm{K}^{+}$-ATPase) (Sigma, Germany). The activity of $\mathrm{Ca}^{2+}$-ATPases was determined in the incubation medium of the following composition: $50 \mathrm{mM}$ of $\mathrm{NaCl}, 100 \mathrm{mM}$ of $\mathrm{KCl}, 5 \mathrm{mM}$ of $\mathrm{MgCl}_{2}, 5 \mathrm{mM}$ of $\mathrm{Na}_{2} \mathrm{ATP}, 20 \mathrm{mM}$ of hepes, $1 \mathrm{mM}$ of ouabain, $0.2 \%$ saponin ( $\mathrm{pH} 7.4)$. The activity of plasma membrane $\mathrm{Ca}^{2+}$-ATPase (PMCA) was calculated by the difference between activities that determined in the medium with $1 \mathrm{mM}$ of thapsigargin (selective inhibitor of $\mathrm{Ca}^{2+} / \mathrm{Mg}^{2+}$-ATPase) (Sigma, Germany) in the presence and absence of $\mathrm{Ca}^{2+}$. The activity of sarco (endo) plasmic reticulum $\mathrm{Ca}^{2+}$-ATPase (SERCA) was calculated by the difference between the activities that were determined in medium with calcium ions in the absence and presence of thapsigargin. Mitochondrial ATPase was blocked by $1 \mathrm{mM}$ of $\mathrm{NaN}_{3}$. The measure of enzyme activity was inorganic phosphate $\left(\mathrm{P}_{\mathrm{i}}\right)$ concentration, which was expressed in $\mu \mathrm{mol}$ of $\mathrm{P}_{\mathrm{i}}$ per $1 \mathrm{mg}$ of protein for $1 \mathrm{~min}\left(\mathrm{P}_{\mathrm{i}} \mu \mathrm{mol} /(\mathrm{mg}\right.$ of protein $\times \min )$ ) [18].

The study of enzymatic reactions kinetic properties was carried out in a standard incubation medium, which was modified by the physical and chemical characteristics or certain components composition (incubation time, concentration of protein, ATP, $\mathrm{Na}^{+}, \mathrm{K}^{+}, \mathrm{Ca}^{2+}$. The imaginary kinetic parameters (initial reaction velocity $\left(\mathrm{V}_{0}\right)$, maximum amount of reaction product $\left(\mathrm{P}_{\max }\right)$, reaction time $(\tau)$ ) that characterize $P_{i}$ release reaction during ATP hydrolysis were determined. Michaelis constant $\left(\mathrm{K}_{\mathrm{m}} \mathrm{ATP}\right)$ under substrate (ATP) saturation and maximum velocity of enzymatic reaction $\left(\mathrm{V}_{\text {max }}\right)$ were determined by the Lineweaver and Burk plot [19]. The obtained concentration dependence of the enzymatic reactions rate on the studied reagents was constructed in the coordinates $\{1 / \mathrm{V}$ on $1 / \mathrm{S}\}$, where $\mathrm{S}$ is the reagent concentration and $\mathrm{V}$ is the rate of ATP enzymatic hydrolysis at a certain concentration. The linear function equation that best approximates the experimental data was calculated using the least squares method.
The level of sodium and potassium ions in tissues was determined using the commercial kits (Felicity diagnostics, Ukraine) [20] and the level of total calcium was determined using atomic absorption spectrophotometer C-115M [15].

Student coefficient was calculated to assess the probable difference between the statistical characteristics of alternative data set. The accurate approximation was when $\mathrm{P} \leq 0.05$ [12]. Statistical analysis of the results was carried out using the programs Excel and Origin.

\section{Results and Discussion}

Since the $\operatorname{PrP}^{\mathrm{C}}$ is a substrate for the formation of $\mathrm{PrP}^{\mathrm{Sc}}$, the study of its expression in tissues and organs are important in the explanation the mechanisms of prion diseases pathogenesis. Therefore, the $\mathrm{PrP}^{\mathrm{C}}$ molecular isoform level in the liver and kidneys was determined.

Among the $\operatorname{PrP}^{\mathrm{C}}$ glycoforms the glycosylated forms were predominated. Nonglycosylated form (19-21 kDa) was represented in the smallest amount. In particular, in the one-month rats' liver the diglycosylated form level was 12.43 standard units. The mono- and nonglycosylated forms levels were respectively 14.15 and 8.83 standard units, while in the kidneys, the following values were observed: $23.84,20.22$ and 17.14 standard units, respectively (Fig. 1). Increasing of the di-, mono- and nonglycosylated cellular prion forms level, respectively, by 68,64 and $21 \%$ was determined in the six months rats' liver compared to one month aged rats (Fig. $1 a, b$ ). However, in the animals' of this age kidneys, the studied parameters level increasing was not as rapid (by $40 \%$ ) (Fig. 1c, d). But in old animals' both tissues the cellular prion isoforms expression decreased by about twice compared to mature animals. In addition, a high nonglycosylated forms level was observed in kidneys (Fig. 1).

Similar results are described by Mar Cuadrado-Tejedor et al. [22]. The authors have analyzed the cortex and hippocampus areas of the rats' brain by the Western blotting analysis. The $\operatorname{PrP}^{\mathrm{C}}$ level was increased in both areas in mature animals (38 weeks) compared to young (6 weeks), and it is decreased in old animals 
$\boldsymbol{A}$

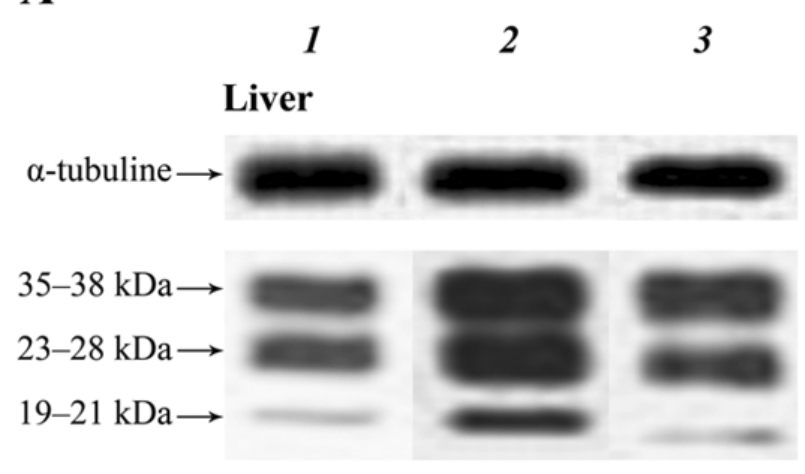

C

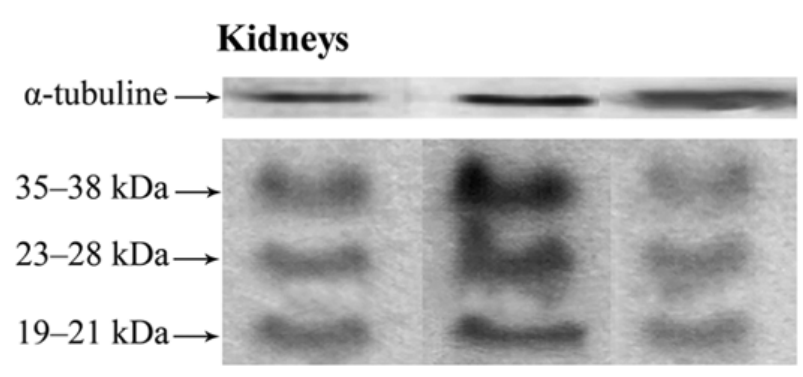

B

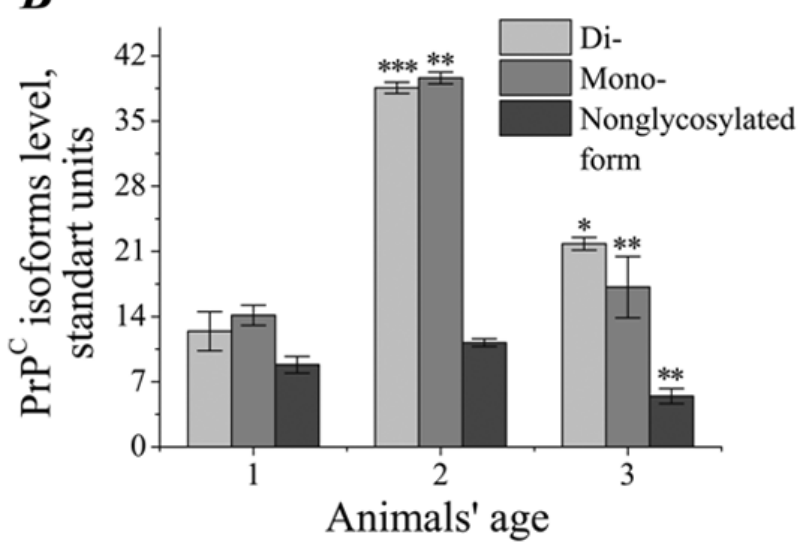

D

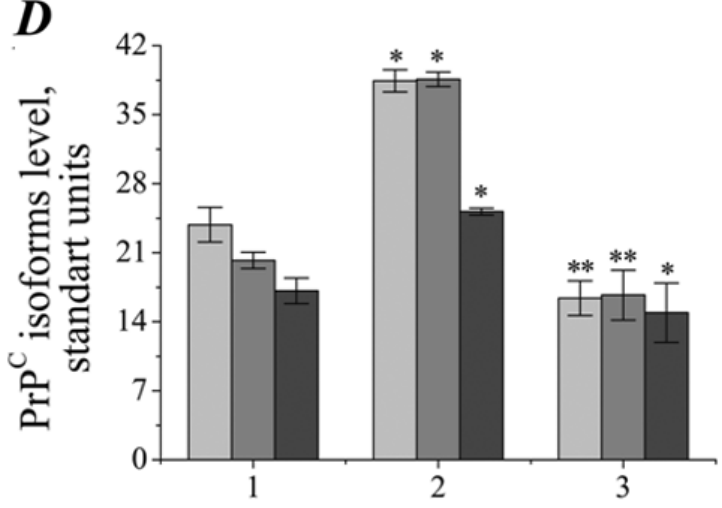

Fig. 1. $\operatorname{PrP}^{\mathrm{C}}$ isoforms level in the liver and kidneys of different age rats $(a, c$ is the western blotting analysis; $b, d$ is the histogram): 1 is one month; 2 is six months; 3 is thirty months $\left(\mathrm{M} \pm \mathrm{m} ;{ }^{*}-\mathrm{P}<0.05 ; * *-\mathrm{P}<0.01 ; * * *-\mathrm{P}<0.001\right.$, the second age group of rats is compared to the first group and the third age group is compared to the second age group)

(56 weeks). Moreover, the amount of non glycosylated forms of the protein increased in age.

Cellular prion is important membrane protein because it is involved in the ions transport through the membrane and in the $\mathrm{Ca}^{2+}$-channels regulation supporting $\mathrm{Ca}^{2+}$-homeostasis $[10,11]$. Therefore, the next task of our study was to investigate the activity of $\mathrm{Na}^{+} / \mathrm{K}^{+}$- and $\mathrm{Ca}^{2+}$-ATPases and the ions $\left(\mathrm{Na}^{+}, \mathrm{K}^{+}, \mathrm{Ca}^{2+}\right)$ level in the different age rats' liver and kidneys. The enzymes activity decreasing depending on increasing the animals' age was demonstrated. In particular, the $\mathrm{Na}^{+} / \mathrm{K}^{+}$ATPase activity decreased, respectively, by 48 and $63 \%$ in the thirty months animals' liver and the kidneys compared to six months animals. PMCA activity in the thirty months rats' the tissues was, respectively, by 81 and $87 \%$ lower compared to six months animals. As for the SERCA, its activity was decreased in 4 and 3 times, respectively, in old animals' tissues (Fig. 2a, c).

The sodium level in the thirty months animals' liver and the kidneys was increased, respectively, by $4-10$ and $2 \%$, compared to the one-month animals, while potassium level was unchanged. Instead $\mathrm{Ca}^{2+}$ level increased significantly (in 4-7 times) in the studied animals' tissues (Fig. 2b, $d$ ).

The values of the kinetic parameters as $\mathrm{V}_{0}$ and $\mathrm{P}_{\max }$ of SERCA hydrolysis in liver cells were decreased in 2 and 5 times, and PMCA in 3 and 7 times in old animals compared to mature animals. In kidneys, the indicators for the respective enzymes were decreased in 2 and 4 times as well as in 3 and 9 times in thirty months animals compared to six months animals. The maximum enzymatic reaction velocity and Michaelis constant were also significantly decreased but the reaction time was increased (Table 1 ).

Based on the results of kinetic analysis we concluded that in old animals the ATP hydrolysis reaction by studied enzymes was less intense and lasts longer and the product was piled up in smaller numbers compared to the one- and six months animals. In addition, the 

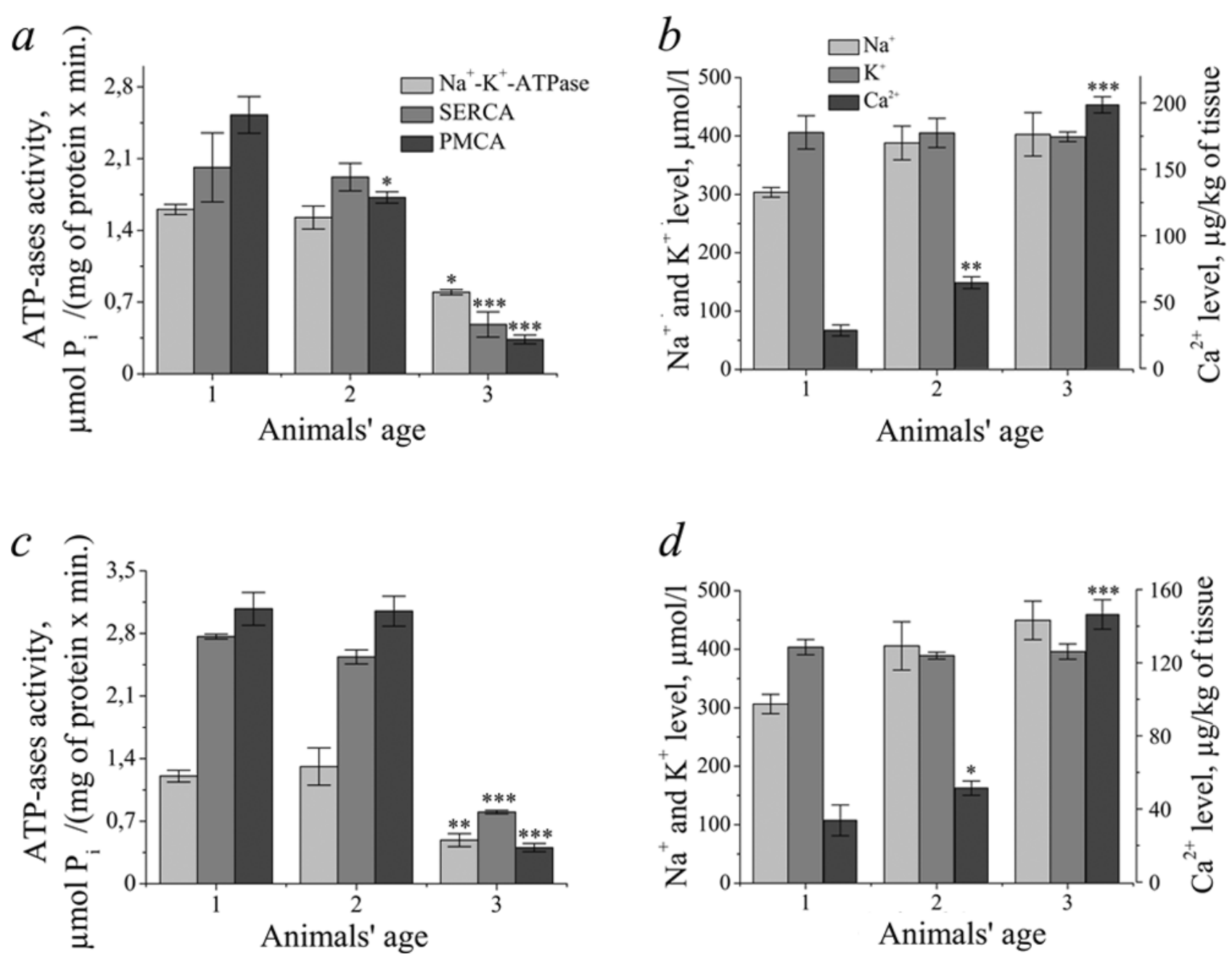

Fig. 2. ATP-ases activity and ions level in the liver $(a, b)$ and kidneys $(c, d)$ of different age rats: 1 is one month; 2 is six months; 3 is thirty months; $(\mathrm{M} \pm \mathrm{m} ; *-\mathrm{P}<0.05$; **- $\mathrm{P}<0.01$; *** $-\mathrm{P}<0.001$, compared to one month rats)

$\mathrm{V}_{\max }$ decreasing due to a transport units reduction (a decreasing their expression in the cell) or decreasing the number of enzymes revolutions. Decrease of the Michaelis constant value in the older animals' tissues indicates a growing affinity to the enzyme substrate. In the thirty months animals' liver and kidneys the $\mathrm{Ca}^{2+}$-ATPases remain its activity under high calcium ions concentration in the medium. It should be noted that the ions concentration value optimum for the $\mathrm{Na}^{+} / \mathrm{K}^{+}$-ATPase is shifting towards the $\mathrm{Na}^{+}$ level increase which is consistent with a slight increase of these ions in the tissues as a whole. We assume that depending on age the cells $\mathrm{Na}^{+} /$ $\mathrm{K}^{+}$electrochemical cytoplasmic membrane gradient is disturbed due to the $\mathrm{Na}^{+} / \mathrm{K}^{+}$-ATPase activity decreasing.

Correlation analysis between the $\mathrm{PrP}^{\mathrm{C}}$ level, $\mathrm{Na}^{+} / \mathrm{K}^{+}$- and $\mathrm{Ca}^{2+}$-ATPases activity and sodium, potassium and calcium level in different age animals' liver and the kidneys was carried out. In both tissues, a correlation between the $\operatorname{PrP}^{\mathrm{C}}$ level and ATPases activity was direct strong $(\mathrm{r}=0.754-0.889)$ as well as between the activity of these enzymes with each other $(r=0.975-0.999)$. Between the $\mathrm{Na}^{+} / \mathrm{K}^{+}$-ATPase activity and $\mathrm{Na}^{+}$and $\mathrm{K}^{+}$level mostly inverse middle correlation was demonstrated $(\mathrm{r}=-0.624 \ldots$ -0.681 ) whereas between the $\mathrm{Ca}^{2+}$-ATPases activity and $\mathrm{Ca}^{2+}$ level the correlation was inverse strong $(\mathrm{r}=-0.989 \ldots-0.999)$ (Table 2).

Thus, there is a correlation between the cellular prion level and ion transporters activity, in particular the $\mathrm{Na}^{+} / \mathrm{K}^{+}$- and $\mathrm{Ca}^{2+}$ ATPases, in the different age rats' liver and the kidneys. Perhaps, this dependence is due to similar functions and localization of studied proteins in the body. 
Kinetic parameters of ATP hydrolysis

\begin{tabular}{|c|c|c|c|c|}
\hline \multicolumn{5}{|c|}{ Liver } \\
\hline \multirow{2}{*}{ Kinetic parameters } & \multirow{2}{*}{ Enzymes } & \multicolumn{3}{|c|}{ Animals' age, months } \\
\hline & & 1 & 6 & 30 \\
\hline $\begin{array}{l}\mathrm{V}_{0}\left(\mathrm{P}_{\mathrm{i}} \mu \mathrm{mol} /(\mathrm{mg} \text { of }\right. \\
\text { protein } \times \mathrm{min}))\end{array}$ & $\begin{array}{c}\mathrm{Na}^{+} / \mathrm{K}^{+}-\mathrm{ATPase} \\
\text { SERCA } \\
\text { PMCA }\end{array}$ & $\begin{array}{l}0.538 \\
1.163 \\
1.087 \\
\end{array}$ & $\begin{array}{c}0.396 \\
0.625^{*} \\
0.903\end{array}$ & $\begin{array}{c}0.262 * \\
0.384 * \\
0.309 * * * \\
\end{array}$ \\
\hline $\mathrm{P}_{\max }\left(\mathrm{P}_{\mathrm{i}} \mu \mathrm{mol} / \mathrm{mg}\right.$ of protein $)$ & $\begin{array}{c}\mathrm{Na}^{+} / \mathrm{K}^{+}-\mathrm{ATPase} \\
\text { SERCA } \\
\text { PMCA }\end{array}$ & $\begin{array}{l}1.311 \\
2.323 \\
3.097 \\
\end{array}$ & $\begin{array}{l}1.089 \\
2.596 \\
2.339\end{array}$ & $\begin{array}{c}0.588 * \\
0.501 * * * \\
0.349 * * *\end{array}$ \\
\hline $\mathrm{t}(\min )$ & $\begin{array}{c}\mathrm{Na}^{+} / \mathrm{K}^{+} \text {-ATPase } \\
\text { SERCA } \\
\text { PMCA }\end{array}$ & $\begin{array}{l}2.437 \\
1.998 \\
2.849 \\
\end{array}$ & $\begin{array}{c}2.750 \\
2.151 * * \\
2.590\end{array}$ & $\begin{array}{c}3.244 \\
4.305 * * \\
1.131 * * \\
\end{array}$ \\
\hline $\begin{array}{l}\mathrm{V}_{\max }\left(\mathrm{P}_{\mathrm{i}} \mu \mathrm{mol} /(\mathrm{mg} \text { of }\right. \\
\text { protein } \times \min ))\end{array}$ & $\begin{array}{c}\mathrm{Na}^{+} / \mathrm{K}^{+}-\mathrm{ATPase} \\
\text { SERCA } \\
\text { PMCA }\end{array}$ & $\begin{array}{l}0.410 \\
4.773 \\
4.209 \\
\end{array}$ & $\begin{array}{l}0.364 \\
4.552 \\
4.073 \\
\end{array}$ & $\begin{array}{c}0.346 \\
0.697 * * * \\
0.366^{* * *} \\
\end{array}$ \\
\hline $\mathrm{K}_{\mathrm{m}}(\mathrm{mmol} / \mathrm{l})$ & $\begin{array}{c}\mathrm{Na}^{+} / \mathrm{K}^{+}-\mathrm{ATPase} \\
\mathrm{SERCA} \\
\text { PMCA } \\
\end{array}$ & $\begin{array}{l}0.438 \\
3.873 \\
2.238 \\
\end{array}$ & $\begin{array}{l}0.336 \\
3.909 \\
3.081 \\
\end{array}$ & $\begin{array}{c}0.453 * \\
1.479 * * \\
0.541 * * * \\
\end{array}$ \\
\hline \multicolumn{5}{|c|}{ Kidneys } \\
\hline \multirow{2}{*}{ Kinetic parameters } & \multirow{2}{*}{ Enzymes } & \multicolumn{3}{|c|}{ Animals' age, months } \\
\hline & & 1 & 6 & 30 \\
\hline $\begin{array}{l}\mathrm{V}_{0}\left(\mathrm{P}_{\mathrm{i}} \mu \mathrm{mol} /(\mathrm{mg} \text { of }\right. \\
\text { protein } \times \min ))\end{array}$ & $\begin{array}{c}\mathrm{Na}^{+} / \mathrm{K}^{+}-\mathrm{ATPase} \\
\text { SERCA } \\
\text { PMCA }\end{array}$ & $\begin{array}{l}0.698 \\
1.363 \\
1.337 \\
\end{array}$ & $\begin{array}{c}0.569 \\
0.881 * \\
1.010\end{array}$ & $\begin{array}{c}0.159 * * * \\
0.420 * * \\
0.334 *\end{array}$ \\
\hline $\mathrm{P}_{\max }\left(\mathrm{P}_{\mathrm{i}} \mu \mathrm{mol} / \mathrm{mg}\right.$ of protein $)$ & $\begin{array}{c}\mathrm{Na}^{+} / \mathrm{K}^{+}-\mathrm{ATPase} \\
\text { SERCA } \\
\text { PMCA }\end{array}$ & $\begin{array}{l}1.057 \\
3.266 \\
3.628 \\
\end{array}$ & $\begin{array}{l}0.893 \\
3.207 \\
3.853 \\
\end{array}$ & $\begin{array}{c}0.382 * * \\
0.866^{* * *} \\
0.410 * * *\end{array}$ \\
\hline $\mathrm{t}(\min )$ & $\begin{array}{c}\mathrm{Na}^{+} / \mathrm{K}^{+}-\mathrm{ATPase} \\
\text { SERCA } \\
\text { PMCA }\end{array}$ & $\begin{array}{l}1.514 \\
2.396 \\
2.713 \\
\end{array}$ & $\begin{array}{l}1.569 \\
2.440 \\
2.815 \\
\end{array}$ & $\begin{array}{c}2.399 * \\
3.061 \\
3.229 \\
\end{array}$ \\
\hline $\begin{array}{l}\mathrm{V}_{\max }\left(\mathrm{P}_{\mathrm{i}} \mu \mathrm{mol} /\right. \\
(\mathrm{mg} \text { of protein } \times \min ))\end{array}$ & $\begin{array}{c}\mathrm{Na}^{+} / \mathrm{K}^{+}-\mathrm{ATPase} \\
\text { SERCA } \\
\text { PMCA }\end{array}$ & $\begin{array}{l}0.660 \\
8.569 \\
4.189\end{array}$ & $\begin{array}{l}0.638 \\
8.244 \\
5.814\end{array}$ & $\begin{array}{c}0.417 * \\
1.031 * * * \\
0.507 * * *\end{array}$ \\
\hline $\mathrm{K}_{\mathrm{m}}(\mathrm{mmol} / \mathrm{l})$ & $\begin{array}{c}\mathrm{Na}^{+} / \mathrm{K}^{+}-\mathrm{ATPase} \\
\text { SERCA } \\
\text { PMCA } \\
\end{array}$ & $\begin{array}{l}0.746 \\
6.009 \\
1.436 \\
\end{array}$ & $\begin{array}{c}0.885 \\
6.117 \\
2.847^{* *} \\
\end{array}$ & $\begin{array}{c}0.945 \\
1.599 * * * \\
0.904 * * * \\
\end{array}$ \\
\hline
\end{tabular}

Comment: $\mathrm{V}_{0}$ is initial reaction velocity; $\mathrm{P}_{\max }$ is maximum amount of reaction product; $\tau$ is reaction time; $\mathrm{V}_{\max }$ is maximum velocity of enzymatic reaction; $\mathrm{K}_{\mathrm{m}}$ is Michaelis constant

Table 2

Pearson correlation coefficient for tissues biochemical parameters

\begin{tabular}{|c|c|c|c|c|c|c|c|c|}
\hline \multirow{2}{*}{ Tissues } & \multirow{2}{*}{\multicolumn{2}{|c|}{ Parameters }} & \multicolumn{3}{|c|}{ Activity of } & \multicolumn{3}{|c|}{ Level of } \\
\hline & & & $\mathrm{Na}^{+} / \mathrm{K}^{+}$-ATPase & SERCA & PMCA & $\mathrm{Na}^{+}$ & $\mathrm{K}^{+}$ & $\mathrm{Ca}^{2+}$ \\
\hline $\begin{array}{l}\text { Liver } \\
\text { Kidneys }\end{array}$ & \multicolumn{2}{|c|}{$\operatorname{PrP}^{\mathrm{C}}$ level } & $\begin{array}{l}0.873 \\
0.831 \\
\end{array}$ & $\begin{array}{l}0.889 \\
0.686 \\
\end{array}$ & $\begin{array}{l}0.766 \\
0.754 \\
\end{array}$ & $\begin{array}{l}-0.236 \\
-0.118 \\
\end{array}$ & $\begin{array}{c}0.866 \\
-0.624 \\
\end{array}$ & $\begin{array}{l}-0.812 \\
-0.657 \\
\end{array}$ \\
\hline $\begin{array}{l}\text { Liver } \\
\text { Kidneys }\end{array}$ & \multirow{3}{*}{ 营 } & $\begin{array}{l}\mathrm{Na}^{+} / \mathrm{K}^{+}- \\
\text {ATPase }\end{array}$ & & $\begin{array}{l}0.999 \\
0.975\end{array}$ & $\begin{array}{l}0.982 \\
0.992\end{array}$ & $\begin{array}{l}-0.681 \\
-0.650\end{array}$ & $\begin{array}{c}0.999 \\
-0.085\end{array}$ & $\begin{array}{l}-0.993 \\
-0.965\end{array}$ \\
\hline $\begin{array}{l}\text { Liver } \\
\text { Kidneys }\end{array}$ & & SERCA & & & $\begin{array}{l}0.976 \\
0.995 \\
\end{array}$ & $\begin{array}{l}-0.656 \\
-0.803 \\
\end{array}$ & $\begin{array}{l}0.999 \\
0.139\end{array}$ & $\begin{array}{l}-0.989 \\
-0.999 \\
\end{array}$ \\
\hline $\begin{array}{l}\text { Liver } \\
\text { Kidneys }\end{array}$ & & PMCA & & & & $\begin{array}{l}-0.805 \\
-0.741\end{array}$ & $\begin{array}{l}0.983 \\
0.042\end{array}$ & $\begin{array}{l}-0.997 \\
-0.991\end{array}$ \\
\hline $\begin{array}{l}\text { Liver } \\
\text { Kidneys }\end{array}$ & \multirow{2}{*}{ 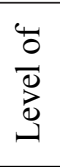 } & $\mathrm{Na}^{+}$ & & & & & $\begin{array}{l}-0.690 \\
-0.702\end{array}$ & $\begin{array}{l}0.759 \\
0.827\end{array}$ \\
\hline $\begin{array}{l}\text { Liver } \\
\text { Kidneys }\end{array}$ & & $\mathrm{K}^{+}$ & & & & & & $\begin{array}{l}-0.995 \\
-0.179\end{array}$ \\
\hline
\end{tabular}

The Animal Biology, 2016, vol. 18, no. 1 


\section{Conclusions}

1. The age dynamics of cellular prion level in the laboratory animals' liver and the kidneys was demonstrated. $\operatorname{PrP}^{\mathrm{C}}$ level is the smallest in young animals' tissues and it was intense accumulated in six months animals. With the animals' age increasing the $\operatorname{PrP}^{\mathrm{C}}$ level in the body decreases.

2. The activities of $\mathrm{Na}^{+} / \mathrm{K}^{+}$- and $\mathrm{Ca}^{2+}$ ATPases in prion replication tissues decrease depending on increasing of the animals' age. The calcium ions were accumulated. The sodium level slightly increased and potassium level did not significantly change. In older animals hydrolysis reaction was less intense and lasts longer compared to mature and young animals.

3. There is a correlation between the studied protein level and transport enzymes activity in prion replicating tissues of the different ages animals.

Prospects for future research is to identify the relationship between the cellular prion level and ATPases activity in other organs of rats' prion replication system.

1. Verbitsky P. I. Spongioform encephalopathy in cattle and other prion infections. Kyiv, Vetinform, 2005, 240 p. (in Ukrainian)

2. Hegde R. S., Tremblay P., Groth D., De Armond S. J., Prusiner S. B., Lingappa V. R. Transmissible and genetic prion diseases share a common pathway of neurodegeneration. Nature. 1999, vol. 402, pp. 822-826.

3. Prusiner S. B. Genetic and infectious prion diseases. Arch. Neurol. 1993, vol. 50, pp. 1129-1153.

4. Büeler H., Fischer M., Lang Y., Bluethmann H., Lipp H. P., DeArmond S. J., Prusiner S. B., Aguet M., Weissmann C. Normal development and behaviour of mice lacking the neuronal cellsurface PrP protein. Nature, 1992, vol. 356, pp. 577-582.

5. Criado J. R., Sánchez-Alavez M., Conti B., Giacchino J. L., Wills D. N., Henriksen S. J., Race R., Manson J. C., Chesebro B., Oldstone M. B. Mice devoid of prion protein have cognitive deficits that are rescued by reconstitution of PrP in neurons. Neurobiol. Dis. 2005, vol. 19, pp. 255-265.

6. Nazor K. E., Seward T., Telling G. C. Motor behavioral and neuropathological deficits in mice deficient for normal prion protein expression. Biochim. Biophys. Acta. 2007, vol. 1772, pp. 645-653.
7. Steele A. D., Lindquist S., Aguzzi A. The prion protein knockout mouse: a phenotype under challenge. Prion. 2007, vol. 1, pp. 83-93.

8. Linden R. Physiology of the Prion Protein. Physiol Rev. 2008, vol. 88, pp. 673-728.

9. Fournier J. G. Cellular prion protein electron microscopy: attempts/limits and clues to a synaptic trait. Implications in neurodegeneration process. Cell Tissue Res. 2008, vol. 332, N 1, pp. 1-11.

10. Vlizlo V. V., Stadnyk V. V., Major Ch. Ya., Verbitsky P. I. Physiological prion and its role in the functioning of the cell. The Animals biology. 2008, vol. 10, N 1-2, pp. 9-23. (in Ukrainian)

11. Peggion C., Bertoli A., Sorgato M. C. Possible role for $\mathrm{Ca}^{2+}$ in the pathophysiology of the prion protein? BioFactors. 2011, vol. 37, pp. 241-249.

12. Major Ch. Ya. The content of physiological prion in peripheral part of rats' prion-replication system under the action of glicoseaminoglycans series drugs. $\mathrm{PhD}$ thesis, Institute of Animal Biology NAAS of Ukraine. Lviv, 2010. 16 p. (in Ukrainian).

13. Stadnyk V. V. Biochemical features of prion-protein at health and disease. $\mathrm{PhD}$ thesis, Institute of Animal Biology NAAS. Lviv, 2008. 15 p. (in Ukrainian)

14. Lowry O. N., Rosenbrough N. I., Forr A. L. Randall R. J. Protein measurement with the Folin phenol reagent. J. Biol. Chem. 1951, vol. 193, N 1, pp. 265-275.

15. Vlizlo V. V. Laboratory methods of research in biology, stockbreeding and veterinary medicine: a guide. Lviv, Spolom, 2012, 764 p. (in Ukrainian)

16. Ostapchenko L. I., Mikhailik I. V. Biological membranes: methods for studying the structure and function. Kyiv, publishing center "Kyiv University”, 2006, 215 p. (in Ukrainian)

17. Jorgensen P. L. Purification of $\mathrm{Na}^{+}-\mathrm{K}^{+}$ATPase: enzyme sources, preparative problems, and preparation from mammalian kidney. Methods in enzymology. 1988, vol. 156, pp. 29-43.

18. Rathbun W., Betlach V. Estimation of enzymically produced orthophosphate in the presence of cysteine and adenosine triphosphate. Anal. Biochem. 1969, vol. 28, pp. 436-447.

19. Keleti T. Fundamentals of enzyme kinetics. Moscow, Mir, 1990. (in Russian)

20. Tytsa N. Encyclopedia of wedge. lab. tests. Moscow, Labynform, 1997, pp. 225-226. (in Ukrainian)

21. Lakin G. F. Biometry. Moscow, HS, 1990. 352 p. (in Russian)

22. Cuadrado-Tejedor M., Irujo A., Paternain B., Madrid M., Velayos J. Cellular Prion Protein and Sexual Dimorphic. Areas in Rodents. Correlates with Alzheimer Disease. Neuroscience \& Medicine. 2011, vol. 2, pp. 384-391. 